\title{
ANALISIS PENGARUH KUALITAS PELAYANAN DAN STRATEGI PRODUK TERHADAP LOYALITAS KONSUMEN PADA RESTORAN SARI ROSO
}

\author{
Oleh: \\ Titin Maidarti ${ }^{1)}$, Meryati $^{2}$ \\ titin2meidarti@gmail.com ${ }^{1)}$,.merry.santoso@(atlover.com ${ }^{2}$ \\ Sekolah Tinggi Ilmu Ekonomi IPWI Jakarta ${ }^{1,2}$
}

\begin{abstract}
ABSTRAK
Pada konsep marketing, loyalitas erat kaitannya dengan konsumen atau loyalitas konsumen yang tidak lain merupakan bentuk kesetiaan konsumen terhadap produk tertentu dan bagi perusahaan dengan memiliki konsumen yang loyal tentu akan memberi keuntungan, di antaranya tidak mudah konsumen tersebut dipengaruhi agar berpindah ke produk pesaing, bahkan konsumen yang loyal akan besar kemungkinan untuk selalu memberi rekomendasi kepada konsumen lain untuk memanfaatkan produk tersebut.

Adapun dalam penelitian ini yang menjadi fokus penelitian adalah pelaksanaan bauran pemasaran melalui strategi promosi dan strategi produk yang dikaitkan pada tingkat loyalitas konsumen. Jadi tujuan dari penelitian ini adalah untuk mengetahui bagaimana dampak pengaruh dan seberapa besar kontribusi pengaruh antara strategi promosi dan strategi produk terhadap peningkatan kualitas loyalitas konsumen. Tujuan dari penelitian ini adalah untuk menganalisa bagaimana dan sejauhmana pengaruh kualitas pelayanan dan strategi produk dalam meningkatkan loyalitas konsumen pada Restoran Sari Roso.

Peneliti menentukan banyaknya populasi penelitian yang diambil secara acak adalah berjumlah 100 orang konsumen dan kemudian digunakan teknik penarikan sampel dengan menggunakan model rumus Slovin sehingga diperoleh 50 responden penelitian. Teknik pengumpulan data menggunakan observasi, wawancara, dan angket/kuesioner. Kategori jawaban responden penelitian terhadap angket terdiri atas lima skala berdasarkan skala Likert. Dalam pengolahan data dibantu dengan menggunakan program SPSS. Pengujian statistik yang digunakan adalah dengan perhitungan uji validitas, uji reliabilitas, koefisien korelasi, koefisien determinasi, uji hipotesa, dan analisa regresi.

Kualitas pelayanan dan strategi produk berpengaruh positif terhadap loyalitas konsumen Restoran Sari Roso, dengan persamaan regresi berganda yaitu sebagai berikut: $Y=4,731+0,934 X 1+1,281 X 2$.
\end{abstract}

Kata Kunci: Kualitas Pelayanan, Strategi Produk, Loyalitas Konsumen

\section{PENDAHULUAN}

Kualitas pelayanan merupakan salah satu faktor penting bagi keberhasilan suatu restoran sebagai perusahaan jasa saat ini. Karena dewasa ini masalah kepuasan dan loyalitas konsumen melalui kualitas pelayanan terbaik telah menjadi komitmen bagi restoran dalam meningkatkan tingkat penjualan produknya (barang/jasa) dan dalam menjalankan roda bisnisnya. Sejalan dengan hal tersebut di atas bahwa tidak ada satupun restoran yang mampu bertahan apabila restoran tersebut tidak mampu menjual barangbarang atau jasa-jasa yang dihasilkannya. Hal demikian menunjukkan bahwa betapa pentingnya peranan pemasaran dalam 
mempertahankan kelangsungan hidup suatu restoran.

Sebagaimana diketahui bahwa dalam keadaan normal, suatu restoran akan berusaha menjual produknya baik berupa makanan maupun minuman sebanyak-banyaknya. Salah satu tujuannya adalah untuk mendapatkan laba yang memadai sehingga restoran tersebut mampu tetap berjalan dan berkembang. Sejalan dengan hal tersebut di atas bahwa tidak ada satupun restoran yang mampu bertahan apabila restoran tersebut tidak mampu menjual makanan dan minuman yang dihasilkannya. Ini berarti bagaimanapun juga baiknya kegiatan-kegiatan lain dalam restoran, bila restoran tidak mampu menjual makanan dan minuman yang dihasilkannya, maka restoran tersebut akan hancur. Hal demikian menunjukkan bahwa betapa pentingnya peranan pemasaran dalam mempertahankan kelangsungan hidup suatu restoran, sejalan dengan penelitian oleh Sigit (2017) bahwa kualitas pelayanan adalah totalitas fitur dan karakteristik produk atau jasa yang bergantung pada kemampuannya untuk memuaskan kebutuhan konsumen yang dinyatakan atau tersirat. Dalam kesempatan apapun, sebuah perusahaan harus berusaha mempertahankan kemantapan posisi sebuah produk dalam suatu pasar.

Namun pada sebagian besar kelompok produk, lebih dari 90 persen penjualan dan keuntungannya justru datang dari produk sejenis yang sudah ada. Pemikiran sederhana bahwa sebuah perusahaan harus memperkenalkan satu produk baru setelah yang lainnya pada saat tidak terdapat kebutuhan konsumen, atau positioning yang jelas, merupakan pemikiran yang tidak masuk akal. Sejalan dengan hal tersebut di atas bahwa tidak ada satupun pengusaha atau perusahaan yang mampu bertahan apabila pengusaha atau perusahaan tersebut tidak mampu menjual barangbarang atau jasa-jasa yang dihasilkannya. Ini berarti bagaimanapun juga baiknya kegiatan-kegiatan lain dalam perusahaan, bila pengusaha atau perusahaan tidak mampu menjual barang/jasa yang dihasilkannya, pengusaha ataupun perusahaan tersebut akan mati. Hal demikian menunjukkan bahwa betapa pentingnya peranan pemasaran dalam mempertahankan kelangsungan hidup pengusaha ataupun perusahaan.

Pengusaha atau perusahaan yang ingin maju dan berkembang harus merubah orientasinya dari produk ke bidang pasar atau istilahnya market orientasi. Di samping itu pengusaha atau perusahaan tidak boleh bersifat pasif dalam memasarkan produknya, artinya hanya menunggu konsumen, tetapi sebaiknya bersifat aktif dalam mencari pelangan. Menurut penelitian Nirma Kuriwati (2017:2) kualitas produk merupakan hal yang penting yang harus diusahakan oleh perusahaan jika ingin bersaing di pasar guna memuaskan kebutuhan konsumen.

Pengusaha atau perusahaan perlu memanfaatkan peluang yang ada dengan menggunakan kebijaksanaan pemasaran untuk merebut pembeli potensial. Kebijaksanaan pemasaran yang perlu diperhatikan dalam merebut pembeli potensial adalah kebijaksanaan produk, harga, promosi, dan distribusi. Begitu pula dengan Restoran Sari Roso yang menghadapi persaingan, untuk itu Restoran Sari Roso telah memperluas jaringan pemasarannya guna mempertahankan dan bahkan menjaring konsumen yang lebih banyak maka perusahaan menerapkan strategi bauran pemasaran di antaranya yaitu tetap mempertahankan kualitas pelayanan dan strategi produk. Tetapi sampai sejauhmanakah kedua strategi tersebut dapat meningkatkan loyalitas konsumen dari Restoran Sari Roso akan di analisa dalam jurnal ini.

\section{TUJUAN PENELITIAN}

Tujuan penelitian ini adalah untuk menganalisis pengaruh kualitas pelayanan dan strategi produk terhadap loyalitas konsumen pada Restoran Sari Roso. 


\section{TELAAH LITERATUR DAN \\ PENGEMBANGAN \\ PROPOSISI/HIPOTESIS \\ Kualitas Pelayanan}

Pemahaman terhadap kualitas pelayanan memberikan arti penting bagi terwujudnya suatu pelayanan yang unggul. Layanan yang dimaksud dalam penelitian ini adalah layanan yang sesuai dengan standar yang telah ditentukan, misalnya proses pengenalan produk secara baik terhadap konsumen/konsumen.

Pengertian kata pelayanan (service) atau biasa disebut juga dengan jasa, menurut Kotler (2002:83) dinyatakan sebagai berikut "a service is any act or performance that one party can offer to other that is essentially intangible and does not result in the ownship of anything. Its production may or may not be tied to a physical product". Artinya, bahwa jasa adalah setiap kegiatan atau manfaat yang ditawarkan oleh suatu pihak pada pihak lain dan pada dasarnya tidak terwujud serta tidak menghasilkan kepemilikan sesuatu. Proses produksinya mungkin dikaitkan mungkin juga tidak dikaitkan dengan suatu produk fisik.

Menurut Tjiptono (2004:59) kualitas pelayanan merupakan tingkat keunggulan yang diharapkan dan pengendalian atas tingkat keunggulan tersebut memenuhi harapan konsumen. Kualitas pelayanan (service quality) adalah ukuran seberapa baik suatu layanan menemui kecocokan dengan harapan konsumen. Penyelenggaraan kualitas layanan berarti melakukan kompromi dengan harapan konsumen dengan tata cara yang konsisten.

Sedangkan Moenir (2002:197) memberikan pengertian bahwa "pelayanan adalah merupakan proses pemenuhan kebutuhan melalui aktivitas orang lain". Selanjutnya Moenir (2002:197) menyatakan: agar pelayanan dapat memuaskan bagi orang maupun sekelompok orang yang dilayani maka pelaku pelayanan harus memenuhi 4 persyaratan pokok, yaitu:

1. Tingkah laku yang sopan.

2. Cara penyampaian sesuai dengan ketentuan yang berlaku.
3. Waktu penyampaian yang cepat.

4. Keramahtamahan petugas.

Berdasarkan pendapat para pakar di atas, pelayanan dapat diartikan sebagai setiap kegiatan/aktivitas yang ditawarkan oleh suatu pihak kepada pihak lain, yang pada dasarnya kegiatan tersebut tidak berwujud dengan tujuan utamanya dapat memberikan kepuasan kepada konsumen.

Sedangkan pengertian kata pelayanan umum menurut Keputusan MENPAN NO. 81 tahun 1993 di dalam Pedoman Tatalaksana Pelayanan Umum adalah sebagai berikut: pelayanan umum adalah segala bentuk kegiatan pelayanan umum yang dilaksanakan oleh Instansi Pemerintah di Pusat, di Daerah, dan di lingkungan BUMN/BUMD dalam bentuk barang dan atau jasa, baik dalam rangka upaya pemenuhan kebutuhan masyarakat maupun dalam rangka pelaksanaan ketentuan perundang-undangan.

Mengenai hal yang sama, Moenir (2002:204), menyatakan sebagai berikut: "pelayanan umum adalah sebagai manajemen proses yang kegiatannya diarahkan secara khusus pada terselenggaranya pelayanan guna memenuhi kepentingan umum atau kepentingan perorangan melalui caracara yang tepat dan memuaskan pihak yang dilayani”.

Berdasarkan pendapat di atas dapat dipahami bahwa pelayanan umum merupakan suatu aktivitas/kegiatan yang dilakukan oleh suatu instansi dalam bentuk barang atau jasa yang ditujukan untuk pemenuhan kebutuhan masyarakat dengan cara yang tepat dan memuaskan berdasarkan ketentuan yang berlaku.

Kualitas dapat didefinisikan sebagai sesuatu yang dapat memenuhi keinginan atau kebutuhan konsumen, sehingga konsumen merasa terpuaskan keinginan/kebutuhannya. Jadi kualitas pelayanan dapat diartikan sebagai sesuatu realitas dan persepsi terhadap apa yang diharapkan oleh konsumen atas apa yang telah diberikan oleh perusahaan.

Kata kualitas mengandung banyak definisi dan makna, orang yang berbeda 
akan mengartikannya secara berlainan tetapi dari beberapa definisi yang dapat kita jumpai memiliki beberapa kesamaan walaupun hanya cara penyampaiannya saja biasanya terdapat pada elemen sebagai berikut:

1. Kualitas meliputi usaha memenuhi atau melebihkan harapan masyarakat (konsumen/konsumen).

2. Kualitas mencakup produk, jasa, manusia, proses dan lingkungan.

3. Kualitas merupakan kondisi yang selalu berubah.

Dari uraian di atas, dapat diambil kesimpulan bahwa kualitas pelayanan adalah segala bentuk aktivitas yang dilakukan oleh perusahaan guna memenuhi harapan konsumen/ konsumen. Pelayanan dalam hal ini diartikan sebagai jasa atau service yang disampaikan oleh pemilik jasa yang berupa kemudahan, kecepatan, hubungan, kemampuan, dan keramahtamahan yang ditujukan melalui sikap dan sifat dalam memberikan pelayanan untuk kepuasan konsumen/konsumen.

Untuk menghasilkan kualitas pelayanan yang dapat memenuhi keinginan/harapan para konsumen atau masyarakat, sehingga keinginan/ harapan mereka bisa terpuaskan oleh penyedia jasa (perusahaan/organisasi). Maka pihak perusahaan/organisasi harus menyediakan atau mengadakan berbagai dimensi kualitas pelayanan beserta faktor-faktornya, agar dapat memuaskan keinginan/harapan para konsumennya atau masyarakat tersebut.

Ada lima dimensi kualitas pelayanan yang harus dipenuhi oleh penyedia jasa untuk dapat menilai kualitas pelayanan dalam suatu perusahaan jasa. Kelima dimensi kualitas pelayanan tersebut adalah sebagai berikut :

1) Dapat dipercaya (Reliability). Artinya, kemampuan untuk melaksanakan pelayanan yang dijanjikan secara akurat. Hal ini meliputi pelayanan pada waktu yang telah direncanakan/ditetapkan, akurat dalam perhitungan dan menjaga pelayanan dengan baik dan benar.
2) Cepat tanggap (Responsiveness). Artinya, tanggapan yang cepat dalam memberi bantuan kepada konsumen dan melaksanakan pelayanan tersebut secara layak. Hal itu meliputi pemberian pelayanan secara cepat dan tepat dalam mengatur perjanjian atau peneriamaan pasien dengan cepat dan benar.

3) Jaminan (Assurance). Artinya, pengetahuan dan keterampilan serta tata krama pegawai serta kemampuan mereka untuk mengembangkan kepercayaan dan keyakinan atau tingkat kesopansantunan yang harus dimiliki pegawai di samping kemampuan mereka menawarkan kepercayaan dan rasa percaya diri pihak konsumen.

4) Empati (Empathy). Artinya, yaitu keperdulian dan pemberian perhatian secara individu kepada konsumen. Termasuk di dalamnya adalah mengerti apa yang diinginkan konsumen. Hal itu meliputi kegiatan mempelajari keinginan konsumen, memberikan perhatian secara individu kepada konsumen dan mengenal konsumen secara lebih dekat lagi.

5) Berwujud (Tangibles). Artinya, penampilan dari fasilitas fisik, peralatan, personal, dan alat-alat komunikasi. Hal itu meliputi penampilan pegawai, fasilitas fisik, peralatan dan perlengkapan yang digunakan dalam pelayanan. Tangibles ini merupakan wujud dari suatu service atau jasa mulai dari bangunan, interior, seragam pegawai, peralatan yang dipakai, dan sebagainya yang berwujud.

\section{Strategi Produk}

Produk merupakan titik awal keberhasilan dan kegagalan dalam pemasaran secara keseluruhan, oleh sebab itu setiap pengusaha wajib mengetahui dan memahami berbagai aspek penting produk yang akan dipasarkan dan para pengusaha harus dapat memahami manfaat apa saja yang 
dapat diharapkan para pembeli produknya.

Definisi Produk menurut Kotler (2002:30) bahwa produk adalah segala sesuatu yang dapat ditawarkan ke suatu pasar untuk memenuhi kebutuhan. Produk-produk yang dipasarkan meliputi barang fisik, jasa, orang, tempat, organisasi, dan gagasan.

Produk secara umum diartikan sebagai sesuatu yang dapat memenuhi kebutuhan dan keinginan konsumen. Artinya apapun wujudnya, selama itu dapat memenuhi keinginan konsumen dan kebutuhan kita katakan sebagai produk. Produk sebagai sesuatu yang dapat ditawarkan ke pasar untuk mendapatkan perhatian untuk dibeli, untuk digunakan atau dikonsumsi yang dapat memenuhi keinginan dan kebutuhan.

Dalam praktiknya produk terdiri dari dua jenis yaitu yang berkaitan dengan fisik atau benda berwujud dan tidak berwujud. Benda berwujud merupakan produk yang dapat dilihat, diraba atau dirasakan. Contohnya buku, meja, kursi, rumah, mobil, dan lain-lain. Sedangkan produk yang tidak berwujud biasanya disebut jasa. Jasa dapat disediakan dalam berbagai wahana seperti pribadi, tempat, kegiatan, organisasi, dan ide-ide.

Ciri-ciri karakteristik produk jasa adalah sebagai berikut:

1) Tidak berwujud, artinya tidak dapat dirasakan atau dinikmati sebelum jasa tersebut dibeli.

2) Tidak terpisahkan artinya antara si pembeli jasa dengan si penjual jasa saling berkaitan.

3) Beraneka ragam artinya jasa dapat diperjualbelikan dalam berbagai bentuk.

4) Tidak tahan lama artinya jasa tidak dapat disimpan begitu jasa dibeli maka akan segera dikonsumsi.

Produk yang diinginkan konsumen, baik berwujud maupun yang tidak berwujud adalah produk yang berkualitas tinggi. Artinya produk yang ditawarkan oleh suatu perusahaan ke konsumennya memiliki nilai yang lebih baik dibandingkan dengan produk perusahaan pesaing. Produk yang berkualitas tinggi ini disebut juga produk plus.

Produk yang berkualitas tinggi yang berhasil diciptakan oleh suatu perusahaan akan memberikan berbagai keuntungan baik dalam jangka pendek maupun jangka panjang. Adapun keuntungan produk plus antara lain:

1) Dapat menaikan penjualan, mengingat konsumen akan tertarik untuk membeli dan mempertahankan produk yang memiliki nilai lebih dengan terus melakukan transaksi.

2) Menimbulkan rasa bangga bagi konsumen yang memiliki produk plus-nya di tengah-tengah masyarakat.

3) Menimbulkan rasa kepercayaan yang tinggi sehingga dapat mempertahankan konsumen lama dan menggaet konsumen baru.

4) Menimbulkan kepuasan tersendiri bagi konsumen yang bersangkutan.

Dalam praktiknya untuk menciptakan produk plus bukanlah perkara mudah. Kehadiran produk plus sangat tergantung dari berbagai pihak yang terkait dengan produk tersebut. Secara umum produk plus tergantung dari:

1) Pelayanan yang prima, artinya pelayanan terhadap produk yang dijual harus dilakukan secara baik, sehingga konsumen cepat mengerti dan memahami produk tersebut dibandingkan dengan produk lainnya.

2) Pegawai yang profesional, artinya memiliki kemampuan untuk menjelaskan dan mempengaruhi konsumen sehingga mau membeli produk yang ditawarkan.

3) Sarana dan prasarana yang dimiliki harus dapat menunjang kelebihan dari produk yang dimiliki, seperti kecanggihan dan kelengkapan teknologi yang dimilikinya, sehingga mampu melayani konsumen secara cepat dan tepat.

4) Lokasi dan layout gedung dan ruangan. Hal ini sangat berpengaruh terhadap kenyamanan dan keamanan konsumen selama berhubungan dengan perusahaan. 
Lokasi yang tidak strategis memuat konsumen malas untuk mendatangi perusahaan. Demikian pula dengan layout ruangan yang tidak baik juga menyebabkan konsumen bosan untuk berhubungan dengan perusahaan.

5) Nama baik perusahaan, menjadi jaminan bagi konsumen untuk membeli produk perusahaan. Oleh karena itu perusahaan harus pandai menjaga nama baik, mengingat jasa perusahaan yang ditawarkan merupakan bisnis kepercayaan.

Karena produk perusahaan merupakan jasa yang menjadikan kepercayaan sebagai senjata utama, maka dalam menjalankan bisnisnya perusahaan perlu memperhatikan halhal berikut ini:

1) Kuantitas pegawai dalam melayani konsumen;

2) Kualitas yang disajikan oleh para pegawai terhadap konsumen yang ditunjukkan dari kemampuannya;

3) Teknologi atau peralatan yang digunakan dalam melayani konsumen;

4) Program atau bentuk jasa/produk yang diberikan;

5) Kualitas bagi setiap jasa/produk yang ditawarkan;

6) Ada jaminan terhadap jasa/produk yang diberikan.

\section{Loyalitas Konsumen}

Konsumen atau konsumen adalah kata kunci bagi kesuksesan perusahaan. Peranan yang demikian penting dimaksudkan agar perusahaan berupaya untuk menyusun strategi atau kiat untuk menarik mereka, sehingga mereka menjadi pembeli barang atau jasanya. Perusahaan juga akan terus berusaha agar konsumen yang ada puas atas jasa atau barang yang dijual perusahaan. Dengan kepuasan yang tinggi yang dirasakan konsumen maka konsumen akan loyal terhadap produk atau jasa yang ditawarkan oleh perusahaan.

Mempertahankan pasar yang ada melalui pengembangan loyalitas konsumen merupakan tujuan strategik perusahaan untuk mempertahankan bisnis dan profit mereka (Aminee, 1998). Dalam jangka panjang, loyalitas konsumen merupakan basis penting bagi pengembangan sustainable competitive advantage (keunggulan bersaing yang berkelanjutan), yaitu keunggulan yang dapat direalisasikan melalui upaya-upaya pemasaran (Dick dan Basu, 1994).

Istilah loyalitas konsumen menunjukkan pada kesetiaan konsumen pada objek tertentu, seperti merek, produk, jasa, atau toko. Pada umumnya merek seringkali dijadikan sebagai objek loyalitas konsumen. Loyalitas merek (brand loyalty) mencerminkan loyalitas konsumen pada merek tertentu. Dalam artikel ini, istilah loyalitas konsumen maupun loyalitas merek menunjukkan pada pemahaman yang sama, dan penggunaannya dapat diutarakan secara silih berganti. Konsep loyalitas konsumen telah memberikan banyak perhatian dalam literatur pemasaran dan perilaku konsumen. Loyalitas konsumen memberikan dampak yang signifikan bagi profitabilitas perusahaan. Konsumen yang loyal kemungkinan akan menunjukkan sikap dan perilaku positif, seperti pembelian ulang merek yang sama dan rekomendasi positif yang dapat mempengaruhi konsumen.

Konsep loyalitas konsumen telah memberikan banyak perhatian dalam literatur pemasaran dan perilaku konsumen. Loyalitas konsumen memberikan dampak yang signifikan bagi profitabilitas perusahaan. Konsumen yang loyal kemungkinan akan menunjukkan sikap dan perilaku positif, seperti pembelian ulang merek yang sama dan rekomendasi positif yang dapat mempengaruhi konsumen. Loyalitas pelanggan menurut Kottler dan Keller (2006:57) adalah repeat purchase (kesetiaan terhadap pembelian produk), retention (ketahanan terhadap pengaruh yang negative mengenai perusahaan), retralls (mereferensikan secara total esistensi perusahaan)

Jika hasil evaluasi terhadap suatu merek, produk, atau jasa yang dipilih memenuhi atau melampaui ekspektasinya, maka konsumen tersebut kemungkinan akan 
menunjukkan sikap positif, dan memiliki keinginan untuk membeli/menggunakan kembali merek, produk, atau jasa yang sama (repurchase intentions), dan keinginannya untuk bertindak sebagai referensi bagi orang lain (advocacy intentions).

Loyalitas adalah suatu komitmen yang mendalam untuk membeli kembali atau berlangganan suatu produk atau jasa secara konsisten di masa yang akan datang. Sehingga dapat menyebabkan pengulangan pembelian merek yang sama walaupun ada pengaruh situasi dan berbagai usaha pemasaran yang berpotensi untuk menyebabkan tindakan perpindahan merk, perusahaan untuk mendapatkan loyalitas atau kesetiaan konsumen perlu strategi pemasaran yang tepat dan kompleks. Konsumen akan menjadi loyal pada merek-merek yang berkualitas dan menawarkannya dengan harga yang wajar selain itu para penjual juga beranggapan bahwa konsumen akan menjadi loyal pada suatu produk jika produk tersebut mudah didapatkan saat dibutuhkan, dan yang tidak kalah penting loyalitas terbentuk melalui promosi yang ditawarkan perusahaan dengan mengkomunikasikan kebaikankebaikan produknya.

Cara sederhana yang digunakan untuk mengukur kepuasan konsumen atau konsumen, yaitu sebagai berikut:

1) Sistem Keluhan dan Saran. Industri yang berwawasan konsumen akan menyediakan formulir bagi konsumen untuk melaporkan kesukaan dan keluhannya. Selain itu dapat berupa kotak saran dan telepon pengaduan bagi konsumen. Alur informassi ini memberikan banyak gagasan baik dan industri dapat bergerak lebih cepat untuk menyelesaikan masalah.

2) Survei Kepuasan Konsumen. Industri tidak dapat menggunakan tingkat keluhan sebagai ukuran kepuasan konsumen. Industri yang responsif mengukur kepuasan konsumen dengan mengadakan survei berkala, yaitu dengan mengirimkan daftar pertanyaan atau menelpon secara acak dari konsumen untuk mengetahui perasaan mereka terhadap berbagai kinerja industri. Selain itu juga ditanyakan tentang kinerja industri saingannya.

3) Ghost Shopping (Konsumen Bayangan). Konsumen bayangan adalah menyuruh orang berpurapura menjadi konsumen dan melaporkan titik-titik kuat maupun titik-titik lemah yang dialami waktu membeli produk dari industri sendiri maupun industri saingannya. Selain itu konsumen bayangan melaporkan apakah wiraniaga yang menangani produk dari industri.

4) Analisa Konsumen yang Beralih. Industri dapat menghubungi konsumen yang tidak membeli lagi atau berganti pemasok untuk mengetahui penyebabnya (apakah harganya tinggi, pelayanan kurang baik, produknya kurang dapat diandalkan dan seterusnya, sehingga dapat diketahui tingkat kehilangan konsumen.

Salah satu konsep dasar dalam memuaskan konsumen, minimal mengacu pada:

1) Keistimewaan yang terdiri dari sejumlah keistimewaan produk, baik keistimewaan langsung maupun keistimewaan atraktif yang dapat memenuhi keinginan konsumen dan dengan demikian dapat memberikan kepuasan dalam penggunaan produk itu.

2) Kualitas terdiri dari segala sesuatu yang bebas dari kekurangan atau kerusakan.

Acuan dari kualitas seperti dijelaskan di atas menunjukan bahwa kualitas selalu berfokus pada kepentingan/kepuasan konsumen (Customer Focused Quality), sehingga dengan demikian produk-produk didesain, diproduksi, serta pelayanan diberikan untuk memenuhi keinginan konsumen. Oleh karena itu, maka kualitas mengacu pada segala sesuatu yang menentukan kepuasan konsumen, suatu produk yang dihasilkan baru dapat dikatakan berkualitas apabila sesuai dengan keinginan konsumen, 
dapat dimanfaatkan dengan baik serta diproduksi dengan cara yang baik dan benar.

Manajer harus berusaha mendorong penjualan dengan memodifikasi karakteristik produk melalui peningkatan kualitas, peningkatan keistimewaan, atau peningkatan gaya.

1) Strategi Peningkatan Kualitas (Quality Improvement), bertujuan meningkatkan kinerja fungsional produk - daya tahan, keandalan, kecepatan, rasanya. Produsen sering dapat memenangkan persaingan dengan meluncurkan peralatan mesin, mobil, televisi, atau deterjen "baru dan lebih baik". Produsen bahan makanan menyebutnya "peluncuran plus" dan mempromosikan suatu bahan tambahan baru atau mengiklankan sesuatu sebagai "lebih kuat", "lebih besar", atau "lebih baik". Strategi ini efektif bila kualitas meningkat, pembeli menerima klaim peningkatan kualitas, dan cukup banyak pembeli yang akan membayar untuk kualitas yang lebih tinggi. Tetapi konsumen tidak selalu bersedia menerima suatu produk "yang ditingkatkan".

2) Strategi Peningkatan Keistimewaan (Feature Improvement), bertujuan menambah keistimewaan baru (seperti ukuran, berat, bahan, bahan tambahan, aksesoris) yang memperluas keanekagunaan, keamanan, atau kenyamanan produk. Misalnya, menambah daya listrik pada mesin pemotong rumput tangan meningkatkan kecepatan dan kemudahan memotong rumput. Produsen mesin pemotong rumput kemudian merancang keamanan produk yang lebih baik. Beberapa produsen telah menambahkan kemampuan konversi sehingga suatu mesin pemotong rumput dapat berfungsi ganda sebagai pengeruk salju. Strategi peningkatan keistimewaan, memiliki beberapa keuntungan. Berbagai keistimewaan baru membangun citra inovatif perusahaan dan memenangkan kesetiaan segmen pasar tertentu yang menghargai keistimewaan tersebut. Beberapa keistimewaan dapat cepat dipasang atau dilepas atau dibuat menjadi pilihan pembeli. Mereka memberikan peluang untuk publikasi gratis dan mendorong antusiasme tenaga penjualan dan distributor. Kelemahan utamanya adalah strategi peningkatan keistimewaan sangat mudah ditiru; kecuali jika ada keuntungan permanen bagi yang pertama di pasar.

3) Strategi Peningkatan Gaya (Style Improvement) bertujuan meningkatkan daya tarik estetis suatu produk. Pengenalan periodik mobil model baru lebih merupakan persaingan gaya, daripada persaingan kualitas atau keistimewaan. Dalam kasus makanan kemasan dan produk rumah tangga, perusahaan memperkenalkan variasi warna dan tekstur dan sering mengubah gaya kemasan, dengan memperlakukannya sebagai perluasan produk. Keuntungan strategi gaya adalah dapat memberikan identitas pasar yang unik pada produk itu dan memenangkan pengikut setia. Namun kompetisi gaya memiliki beberapa masalah. Pertama, sulit untuk memperkirakan apakah orang - dan orang yang mana - akan menyukai suatu gaya baru. Kedua, perubahan biasanya gaya biasanya disertai penghentian produk lama, dan perusahaan berisiko kehilangan konsumen yang menyukai gaya lama.

Adapun untuk mengukur tingkat loyalitas konsumen/konsumen adalah dapat dilihat dari beberapa indikator berikut, yaitu:

1. Kepuasan konsumen/konsumen.

2. Kesetiaan konsumen/konsumen.

3. Perilaku konsumen/konsumen untuk memberitahukan mengenai produk kepada orang lain.

Loyalitas mengacu pada suatu perilaku yang ditujukan dengan pembelian rutin yang didasarkan pada unit pengambilan keputusan. Loyalitas 
mencerminkan seberapa besar kemungkinan seseorang akan beralih ke perusahaan lain. Dengan tingkat loyalitas dari konsumen/konsumen, maka akan mengurangi kerawanan dari persaingan. Loyalitas konsumen merupakan komitmen konsumen terhadap suatu merek, toko atau pemasok berdasarkan sifat positif dan tercermin dalam pembelian ulang yang konsisten.

Tidak hanya konsumen yang loyal saja yang mampu memberi kontribusi yang menguntungkan bagi perusahaan. Tetapi konsumen yang tidak loyal juga dapat memberi kontribusi yang menguntungkan bagi perusahaan karena memiliki daya kritis dan pertimbangan dangat matang terhadap produk yang tidak diminati tersebut, dengan demikian peran informasi produk, kualitas, dan segala atribut yang melekat pada produk akan selalu jadi bagian pertimbangan.

\section{Pengaruh Kualitas Pelayanan dan Strategi Produk terhadap Loyalitas Konsumen}

Semua perusahaan sangat penting mempertahankan loyalitas konsumennya, karena konsumen yang loyal akan mampu memberi kontribusi yang berkelanjutan dan yang menguntungkan bagi perusahaan. Guna meraih dan mempertahankan loyalitas konsumen, perusahaan perlu untuk mengadakan strategi.

Dengan melakukan kualitas pelayanan yang optimal, dimana kualitas sebagai sesuatu yang dapat memenuhi keinginan atau kebutuhan konsumen, sehingga konsumen merasa terpuaskan keinginan/kebutuhannya, maka diharapkan loyalitas konsumen semakin bertumbuh. Serta dengan didukung strategi produk, dimana produk yang diinginkan konsumen, baik berwujud maupun yang tidak berwujud adalah produk yang berkualitas tinggi. Artinya produk yang ditawarkan oleh suatu perusahaan ke konsumennya memiliki nilai yang lebih baik dibandingkan dengan produk perusahaan pesaing. Produk yang berkualitas tinggi ini disebut juga produk plus. Produk yang berkualitas tinggi yang berhasil diciptakan oleh suatu perusahaan akan memberikan berbagai keuntungan baik dalam jangka pendek maupun jangka panjang.

Kedua strategi tersebut yaitu kualitas pelayanan dan strategi produk diharapkan akan mempengaruhi secara positif bagi peningkatan loyalitas konsumen.

Sesuai dengan rumusan masalah yang telah dikemukakan dan uraian tersebut di atas, peneliti mengemukakan hipotesis sebagai berikut:

Ho: Tidak ada hubungan yang signifikan antara kualitas pelayanan dan strategi produk secara bersamasama dengan loyalitas konsumen pada Restoran Sari Roso.

Ha: Ada hubungan yang signifikan antara kualitas pelayanan dan strategi produk secara bersama-sama dengan loyalitas konsumen pada Restoran Sari Roso.

Dalam penelitian ini meliputi dua variabel bebas yaitu variabel $\mathrm{X} 1$ (kualitas pelayanan) dan variabel X2 (strategi produk). Dan satu variabel terikat yaitu variabel Y (loyalitas konsumen). Model hubungan antara variabel bebas dengan variabel terikat dalam penelitian ini dapat lihat pada gambar berikut:

Gambar 1

Kerangka/Konstelasi

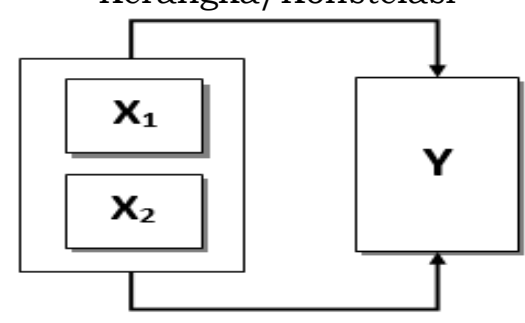

\section{METODE PENELITIAN}

Sampel Penelitian

Penentuan sumber data bergantung pada masalah yang akan diteliti, serta hipotesis yang akan diuji kebenarannya. Pada penelitian ini yang menjadi populasi penelitian adalah para konsumen Restoran Sari Roso, yaitu sebanyak 100 orang konsumen, berdasarkan perhitungan menggunakan rumus Slovin, ditemukan jumlah sampel 
sebanyak 50 orang konsumen pada Restoran Sari Roso.

\section{Desain Penelitian}

Jenis dan rancang penelitian dapat dikelompokkan sesuai tujuan penelitian, pendekatan, tingkat eksplanasi dan jenis data. Penelitian ini tergolong penelitian asosiatif yaitu penelitian yang bersifat mencari hubungan atau pengaruh antara satu variabel dengan variabel lainnya.

\section{Lokasi dan Waktu Penelitian}

Adapun lokasi yang dipilih sebagai tempat penelitian Restoran Sari Roso, J1. Dasa Darma No. 32, Rawa Lumbu, Bekasi. Dengan visi misi "Kebutuhan Karyawan Terpenuhi dan Mempertahankan Kualitas". Waktu penelitian dilaksanakan pada bulan Maret sampai dengan bulan Juni 2018.

\section{Operasionalisasi Variabel}

Dalam penelitian ini variabel bebas adalah kualitas pelayanan (X1) dan strategi produk (X2) variabel terikat adalah loyalitas konsumen $(\mathrm{Y})$.

Tabel 1

Operasionalisasi Variabel

\begin{tabular}{|c|c|}
\hline Variabe1 & Indikator \\
\hline $\begin{array}{c}\text { Loyalitas } \\
\text { Konsumen (Y) }\end{array}$ & $\begin{array}{l}\text { 1. Kepuasan konsumen. } \\
\text { 2. Kesetiaan konsumen. } \\
\text { 3. Perilaku konsumen untuk } \\
\text { memberitahukan mengenai suatu } \\
\text { produk kepada orang lain }\end{array}$ \\
\hline $\begin{array}{c}\text { Kualitas } \\
\text { Pelayanan (X1) }\end{array}$ & $\begin{array}{l}\text { 1. Dapat Dipercaya (Reliability). } \\
\text { 2. Cepat Tanggap (Responsiveness). } \\
\text { 3. Jaminan (Assurance). } \\
\text { 4. Empati (Empathy). } \\
\text { 5. Berwujud (Tangibles). }\end{array}$ \\
\hline $\begin{array}{l}\text { Strategi Produk } \\
\text { (X2) }\end{array}$ & $\begin{array}{l}\text { 1. Kuantitas pegawai dalam restoran } \\
\text { 2. Kualitas yang disajikan oleh para } \\
\text { pegawai terhadap konsumen yang } \\
\text { ditunjukkan dari kemampuannya. } \\
\text { 3. Teknologi atau peralatan yang } \\
\text { digunakan dalam melayani } \\
\text { konsumen. } \\
\text { 4. Program atau bentuk jasa/produk } \\
\text { yang diberikan. } \\
\text { 5. Kualitas bagi setiap jasa/produk } \\
\text { yang ditawarkan. } \\
\text { 6. Ada jaminan terhadap } \\
\text { jasa/produk yang diberikan. }\end{array}$ \\
\hline
\end{tabular}

\section{Prosedur Pengumpulan Data}

Penelitian ini penulis mengumpulkan data yang berhubungan dengan masalah yang sedang diteliti, adapun teknik yang digunakan yaitu sebagai berikut:
1. Penelitian kepustakaan penelitian yang dilakukan dengan cara membaca dan mempelajari literatur yang terdapat di perpustakaan, dengan maksud untuk menempatkan landasan teoritis mengenai masalah pokok yang sedang dibahas.

2. Penelitian Lapangan, penelitian terhadap objek yang diteliti dan pencarian data pada objek penelitian dengan cara observasi, wawancara, penyebaran angket, dan kuisioner

Data diperoleh dari hasil daftar pertanyaan (kuisioner) yang telah dijawab dan diserahkan kembali oleh 50 responden sebagai sampel dalam penelitian ini. Pada proses penelitian memerlukan suatu analisis untuk memperoleh kebenaran data. Hasil analisis tersebut dapat ditafsirkan untuk menjawab suatu pemasalahan yang telah dirumuskan, berdasarkan teknik analisis yang telah ditentukan dan sesuai dengan pemasalah yang akan dikaji. Analisis data merupakan langkah kritis dalam sebuah penelitian, berdasar proses penarikan sampel dan pengumpulan data akan diperoleh data kasar, langkah selanjutnya adalah menginterpretasi data-data tersebut agar dapat ditarik suatu hasil penelitian, dimana hal ini membutuhkan suatu metode. Metode statistik merupakan cara untuk memperoleh data dan menarik kesimpulan-kesimpulan yang logis dari pengolahan data.

Selanjutnya pada subbab-subbab berikut akan dibahas dan dijelaskan mengenai teknik analisa yang digunakan dalam mengelola dan menganalisis datadata yang didapatkan dalam penelitian ini.

\section{Uji Validitas dan Reliabilitas}

Kualitas data penelitian sangat tergantung pada kualitas data yang dipakai di dalam penelitian. Kualitas data penelitian ditentukan oleh instrumen yang digunakan untuk mengumpulkan data untuk menghasilkan data yang berkualitas. Instrumen penelitian yang baik harus memenuhi persyaratan yaitu valid dan reliabel. Untuk mengetahui validitas dan 
reliabilitas kuisioner perlu dilakukan pengujian atas kuisioner dengan menggunakan uji validitas dan uji reliabilitas.

\section{Koefisien Korelasi Berganda}

Sedangkan perhitungan koefisien korelasi berganda menggunakan rumus Pearson Product Moment, guna menguji tingkat korelasi antara variabel bebas dan variabel terikat.

\section{Uji Hipotesis}

Uji hipotesis merupakan suatu prosedur untuk pembuktian kebenaran sifat populasi berdasarkan data sampel. Manfaat uji hipotesis adalah untuk menguji kebenaran suatu hipotesis, dan menentukan keputusan mana yang akan diterima. Sedangkan uji hipotesa untuk koefisien korelasi ganda, menggunkan rumus Uji F.

\section{Analisa Regresi Berganda}

Persamaan analisa regresi berganda yang digunakan adalah sebagai berikut: $\mathrm{Y}=\mathrm{a}+\mathrm{b} 1 \mathrm{X} 1+\mathrm{b} 2 \mathrm{X} 2$.

\section{HASIL DAN PEMBAHASAN Uji Validitas}

Berdasarkan hasil pengujian, nilai korelasi tabel yang diperoleh dari hasil perhitungan $(\mathrm{Df}=\mathrm{N}-2$ dan $=5 \%$ ) adalah sebesar 0,279. Hasil uji validitas terhadap 37 item pertanyaan, ternyata semua instrumen penelitian menunjukkan angka lebih besar dari $r$ tabel. Hal ini menunjukkan bahwa alat ukur yang digunakan telah valid dan dapat digunakan sebagai indikator dalam penelitian ini.

\section{Uji Reliabilitas}

Hasil uji reliabilitas menunjukkan bahwa alat ukur yang digunakan 100\% reliabel $(a>0,6)$ yaitu variabel X1 (kualitas pelayanan) sebesar 0,735, variabel X2 (strategi produk) sebesar 0,881 , dan variabel $Y$ (loyalitas konsumen) sebesar 0,914. Hal ini menunjukkan bahwa semua variabel bebas dan variabel terikat dapat dinyatakan reliabel.

\section{Koefisien Korelasi dan Regresi Berganda}

Tabel 2

Model Summary

\begin{tabular}{|l|r|r|r|r|}
\hline Model & \multicolumn{1}{|c|}{$\mathrm{R}$} & R Square & $\begin{array}{c}\text { Adjusted R } \\
\text { Square }\end{array}$ & $\begin{array}{c}\text { Std. Error of } \\
\text { the Estimate }\end{array}$ \\
\hline 1 & $.886^{2}$ & .784 & .768 & 3.457 \\
\hline
\end{tabular}

a. Predictors: (Constant), Strategi Produk, Kualitas Pelayanan

b. Dependent Variable: Loyalitas Konsumen

Berdasarkan tabel di atas ditemukan bahwa hubungan antara kualitas pelayanan dan strategi produk secara bersama-sama terhadap loyalitas konsumen di Restoran Sari Roso adalah positif dan sangat kuat, yaitu sebesar 0,806 .

\section{Uji Hipotesa}

Uji hipotesa untuk koefisien korelasi ganda menggunakan rumus uji $\mathrm{F}$ adalah 49,061. Dengan taraf kesalahan, yaitu: $5 \%$ dan $\mathrm{Df}=\mathrm{n}-\mathrm{m}-1=47$, kemudian diperoleh $F$ tabel $=3,3541$, berarti $F$ hitung jatuh pada daerah penolakan Ho, maka Ha diterima. Jadi kesimpulannya adalah koefisien korelasi antara faktor kualitas pelayanan dan strategi produk secara bersama-sama terhadap loyalitas konsumen di Restoran Sari Roso adalah signifikan.

\section{Analisa Regresi Berganda}

Hasil perhitungan regresi linier berganda dengan bantuan program SPSS adalah sebagai berikut:

Tabel 3

Coefficients $^{\mathrm{a}}$

\begin{tabular}{|c|c|c|c|c|c|c|}
\hline \multirow{2}{*}{\multicolumn{2}{|c|}{ Model }} & \multicolumn{2}{|c|}{ Unstandardized Coefficients } & \multirow{2}{*}{$\begin{array}{c}\text { Standardized } \\
\text { Coefficients }\end{array}$} & \multirow[b]{2}{*}{$t$} & \multirow[b]{2}{*}{ Sig. } \\
\hline & & B & Std. Error & & & \\
\hline \multirow[t]{3}{*}{1} & (Constant) & 4.731 & 7.329 & & .646 & .524 \\
\hline & $\begin{array}{l}\text { Kualitas } \\
\text { Pelayanan }\end{array}$ & .934 & .196 & .562 & 4.764 & .000 \\
\hline & Strategi Produk & 1.281 & .368 & .410 & 3.480 & .002 \\
\hline
\end{tabular}

Berdasarkan hasil analisa regresi di atas, maka dapat disusun persamaan regresi, yaitu: $\mathrm{Y}=4,731+0,934 \mathrm{X} 1+$ $1,281 \mathrm{X} 2$. Kemudian interpretasi dari persamaan tersebut adalah sebagai berikut:

1) Konstanta $(\mathrm{a}=4,731)$, artinya angka ini menunjukkan kualitas loyalitas konsumen, yaitu pada saat Restoran Sari Roso tidak sama sekali memiliki kualitas kualitas pelayanan yang 
baik dan Restoran Sari Roso tidak memiliki kualitas strategi produk yang baik sama sekali.

2) Koefisien regresi ( $\mathrm{b} 1=0,934)$, artinya jika kualitas kualitas pelayanan yang terjadi bertambah sebesar satu kali maka kualitas loyalitas konsumen di Restoran Sari Roso akan bertambah sebesar 0,934 kali.

3) Koefisien regresi (b2 $=1,281)$, artinya jika tingkat kualitas strategi produk yang terjadi bertambah sebesar satu kali maka kualitas loyalitas konsumen di Restoran Sari Roso akan bertambah sebesar 1,281 kali.

\section{KESIMPULAN}

\section{Simpulan}

- Dari hasil penelitian diketahui bahwa terdapat hubungan positif kuat antara kualitas pelayanan dan strategi produk terhadap loyalitas konsumen pada Restoran Sari Roso.

- Berdasarkan hasil analisa regresi maka didapati fakta bahwa faktor strategi produk adalah faktor yang akan memberikan kontribusi terbesar terhadap peningkatan loyalitas konsumen pada Restoran Sari Roso.

\section{Saran}

Restoran Sari Roso harus lebih memperhatikan kualitas pelayanan demi lebih meningkatkan loyalitas konsumen. Dalam menghasilkan pelayanan yang berkualitas dan harus memenuhi 4 persyaratan pokok, yaitu: tingkah laku yang sopan, cara penyampaian sesuai dengan ketentuan yang berlaku, waktu penyampaian yang cepat, dan keramahtamahan petugas.
- Restoran Sari Roso harus lebih memperhatikan strategi produk demi lebih peningkatkan loyalitas konsumen, karena produk yang diinginkan masyarakat, baik berwujud maupun yang tidak berwujud adalah produk yang berkualitas tinggi. Manajer harus berusaha mendorong peningkatan loyalitas konsumen dengan memodifikasi karakteristik produk melalui peningkatan kualitas, peningkatan keistimewaan, atau peningkatan pelayanan.

\section{DAFTAR PUSTAKA}

Kotler, Philip. 2002. Manajemen Pemasaran: Analisis, Perencanaan, Implementasi dan Pengendalian. Diterjemahkan oleh Ancellawati Hermawan. Jakarta: Salemba Empat.

Kotler, Philip and Kevin Lane Keller. 2006. Manajemen Pemasaran. Jilid 1 Edisi ke 13. Diterjemahkan oleh Bob Sabran. Jakarta: Erlangga.

Kuriwati, Nirma. 2017. Pengaruh Kualitas Produk terhadap Kepuasan dan Dampaknya terhadap Loyalitas konsumen. Jurnal Manajemen. Madura: Universitas Trunojoyo.

Moenir, H. A. S. 2002. Manajemen Pelayanan Umum di Indonesia. Jakarta: Bumi Aksara.

Sigit, Reza Dimas. 2017. Pengaruh kualitas pelayanan terhadap kepuasan konsumen pengguna Jasa Lapangan Futsal. Jurnal Manajemen. Bandung: Fakultas Ekonomi dan Bisnis Universitas Telkom.

Tjiptono, Fandy. 2004. Manajemen Jasa. Yogyakarta: Andi Offset. 